\title{
Thermal requirements, development and number of generations of Duponchelia fovealis (Zeller) (Lepidoptera: Crambidae)
}

\author{
JOÃO P.P. PAES ${ }^{1}$, VICTOR L.S. LIMA ${ }^{2}$, DIRCEU PRATISSOLI ${ }^{2}$, JOSÉ R. \\ CARVALHO $^{2}$, VICTOR D. PIROVANI ${ }^{3}$ and REGIANE C.O.F. BUENO ${ }^{4}$ \\ ${ }^{1}$ Instituto Federal de Santa Catarina/IFSC, Campus Canoinhas, Avenida Expedicionários, \\ 2150, Campo da Água Verde, 89460-000 Canoinhas, SC, Brazil \\ ${ }^{2}$ Laboratório de Entomologia/NUDEMAFI, Departamento de Agronomia, Centro de Ciências Agrárias e Engenharias/CCAE, \\ Universidade Federal do Espírito Santo/UFES, Alto Universitário, s/n, Caixa Postal 16, Guararema, 29500-000 Alegre, ES, Brazil \\ ${ }^{3}$ Instituto Federal de Minas Gerais/IFMG, Campus São João Evangelista, Avenida \\ Primeiro de Junho, 1043, 39705-000 São João Evangelista, MG, Brazil \\ ${ }^{4}$ Departamento de Proteção Vegetal, Universidade Estadual Paulista "Júlio de Mesquita Filho", Faculdade de \\ Ciências Agronômicas, Fazenda Lageado, Rua José Barbosa de Barros, 1780, 18610-307 Botucatu, SP, Brazil
}

Manuscript received on December 19, 2016; accepted for publication on October 24, 2017

\begin{abstract}
In this study, the effect of temperature on the growth of the European pepper moth, Duponchelia fovealis (Zeller), was assessed at five constant temperatures $\left(18,21,24,27\right.$ and $\left.30^{\circ} \mathrm{C}\right)$. The European pepper moth was observed to complete its developmental stages (from egg to adult) at all the temperatures evaluated. From the results, it was evident that temperature affected the rate and development time of all the growth stages, to a significant degree. The length in time of the embryonic, larval, pupal and total (egg-adult) stages was observed to drop as the temperature rose from 18 to $24^{\circ} \mathrm{C}$, but remained constant between 27 and $30{ }^{\circ} \mathrm{C}$. The developmental time in the pre-pupal stage dropped between 18 and $30^{\circ} \mathrm{C}$. The European pepper moth takes 454 degree-days to complete development at $11.7^{\circ} \mathrm{C}$ temperature threshold. The $D$. fovealis survival was thus inversely proportional to temperature over range of 18 to $30^{\circ} \mathrm{C}$. On assessing the number of annual generations for the five largest strawberry-producing municipalities in Espírito Santo State, an average of 5.5 generations per year was estimated. This is a first report of temperature on $D$. fovealis development.
\end{abstract}

Key words: Development rate, developmental thresholds, European pepper moth, longevity, survival.

\section{INTRODUCTION}

Temperature may influence the biological traits of insects including their development, survival,

Correspondence to: Victor Luiz de Souza Lima

E-mail: victor.souzalima@gmail.com

* Contribution to the centenary of the Brazilian Academy of Sciences. longevity, fertility and fecundity (Krechemer and Foerster 2015). According to Manfredi-Coimbra et al. (2001) the increase in temperature up to a specific degree can shorten the length of the developmental phases of the egg, larva and pupa and thus reduce the time of the complete insect cycle. In addition, the increase in temperature may reduce the adult male and female longevity and 
retard embryonic development (Krechemer and Foerster 2015, Moraes and Foerster 2015). Other biological characteristics of the insects also respond better to a certain temperature range. For instance, depending on the species, the survival and fecundity may increase at temperature ranges from 22 to 30 ${ }^{\circ} \mathrm{C}$ (Bavaresco et al. 2002, Martins et al. 2016, Tofangsazi et al. 2012). Therefore, research on the influence of temperature and thermal requirements on the biological parameters of pest insects is very crucial in the understanding of pest behavior, ecology and management (Kang et al. 2009).

The European pepper moth, Duponchelia fovealis Zeller (Lepidoptera: Crambidae) originally from the Mediterranean regions and Canary Islands, is also found as a greenhouse pest in certain parts of Europe, Africa and the Middle East (Ahern 2010, Bonsignore and Vacante 2010). In 2004, this moth was identified in North America (in the USA) and in 2005 in Canada, after which eradication measures were taken (Bethke and Bates 2014, Brambila and Stocks 2010). In Brazil, this pest continues to damage the strawberry crop since 2010, and is mostly present in the states of Paraná, Espírito Santo and southern Minas Gerais (Fornazier et al. 2011, Souza et al. 2013, Zawadneak et al. 2016). Reportedly, the European pepper moth feeds on a minimum of 38 plant families and is a pest on 35 species, ranging from the aquatic to cultivated plants (Brambila and Stocks 2010, Stocks and Hodges 2013). The wide distribution of the European pepper moth geographically, the numerous hosts it lives on and its speedy expansion into many of the strawberry-producing regions are perhaps because of the high degree of adaptability this species exhibits to a variety of environmental conditions. Therefore, studies on the thermal requirements of $D$. fovealis will prove beneficial to generate sufficient data to facilitate the implementation of the management strategies under field conditions, apart from offering a clear insight into the population growth dynamics of this dominant strawberry crop pest.

Therefore, thus far, no other research has been conducted to estimate the influence of constant temperatures on the biological activities of $D$. fovealis. Therefore, the aim of the current study was to assess the influence of temperature on the D. fovealis development and survival, to evaluate its thermal requirements and estimate the number of annual generations for five strawberry producing municipalities in the Espírito Santo State (Venda Nova do Imigrante, Domingos Martins, Vargem Alta, Santa Maria de Jetibá and Muniz Freire).

\section{MATERIALS AND METHODS}

The experiments were performed in the Entomology Sector of the Núcleo de Desenvolvimento Científico e Tecnológico em Manejo Fitossanitário de Pragas e Doenças (NUDEMAFI); this is part of the Centro de Ciências Agrárias e Engenharias (CCAE) of the Universidade Federal do Espírito Santo (UFES), in Alegre, Espírito Santo, Brazil.

\section{REARING $D$. fovealis IN THE LABORATORY}

Duponchelia fovealis adults obtained from the NUDEMAFI laboratory were placed in PVC tubes (20 cm diameter x $20 \mathrm{~cm}$ height), plugged at the lower end with sulfite paper-coated Styrofoam and sealed at the upper end with voile tissue. The insides of the tubes were lined with sulfite paper to receive the eggs laid. A cotton swab with $10 \%$ honey solution was offered to the adults in the glass tubes ( $2 \mathrm{~cm}$ diameter x $5 \mathrm{~cm}$ height). The eggs were then gathered and saved in acrylic jars (15 x 15 x $6 \mathrm{~cm}$ height). After the eggs hatched, the newly emerged caterpillars were placed in plastic pots $(16 \mathrm{~cm}$ diameter $\times 10 \mathrm{~cm}$ height), the lower bases of which were lined with folded paper. Small pieces $\left( \pm 1 \mathrm{~cm}^{3}\right)$ of artificial diet were offered as food, according to the method of Greene et al. (1976). Post larval development, the pupae were 
moved to moistened paper-lined pots. A D. fovealis colony was thus established in the laboratory under temperatures of $25 \pm 1{ }^{\circ} \mathrm{C}$, relative humidity of $70 \% \pm 10 \%$ and photoperiod of 12 hours.

DEVELOPMENT AND SURVIVAL OF D. fovealis AT DIFFERENT TEMPERATURES

The different developmental stages of $D$. fovealis and its survival were assessed in laboratory at five different temperatures $\left(18,21,24,27\right.$ and $\left.30^{\circ} \mathrm{C}\right)$, RH $70 \pm 10 \%$ and 12-hour photoperiod.

To ascertain the duration of the embryonic development, 24-hour old egg masses were incubated at the five different temperatures mentioned above. For each temperature, 120 eggs were used, out of which only 100 were randomly selected for assessment. Daily observation of the eggs was done until hatching and the period of embryo development was recorded.

To study the larval period, the freshly emerged caterpillars were individually inoculated into glass tubes $(8.5 \mathrm{~cm} \times 2.5 \mathrm{~cm}$ in diameter) in which the identical diet used for breeding was placed. The tubes, each containing 100 caterpillars were maintained in air-conditioned chambers for each of the five temperatures. Daily observations were done and the durations and viability of larval, prepupal and pupal phases were recorded.

Once the adults had emerged, a couple were placed in each PVC cage $(10 \mathrm{~cm}$ diameter $\mathrm{x} 10$ $\mathrm{cm}$ height) and fed on the $10 \%$ honey solution. Daily observations were done to assess the adult longevity. Twenty repetitions were performed for each temperature.

\section{STATISTICAL ANALYSIS}

A completely randomized design was selected for the experiment. Five treatments (temperatures) and ten replications were done with each replicate involving 10 individuals, on average. The ShapiroWilk test was used to check the normality of the developmental data. When normal, the data were submitted to one-way ANOVA and the means were compared employing the Tukey test $(P<0.05)$; however, when the data were non-normal, they were submitted to Kruskall-Wallis ANOVA and the means were compared using the Dunn test $(P<0.05)$. Survival curves were assessed applying the Kaplan-Meier method (Kaplan and Meier 1958), analyzed by the LogRank test $(P<0.05)$ and compared with the Holm-Sidak test $(P<0.05)$.

The data on the duration of the development of each life stage, as well as that of the total cycle were analyzed using linear regression according to model $1 / D=a+b T$, where $1 / D$ is the development time, $a$ is the linear coefficient, $b$ is the angular coefficient and $T$ is the temperature. The temperature threshold $\left(T_{\mathrm{t}}\right)$ and the thermal constant $(K)$ in degree-days were estimated with the hyperbola method, employing the equations $T_{\mathrm{t}}$ $=-a / b$ e $K=1 / b$ (Campbell et al. 1974).

Nonlinear models were also tested (Table I), in order to estimate the upper temperature threshold $\left(T_{\mathrm{L}}\right)$ and the optimum temperature $\left(T_{\text {opt }}\right)$ (Briere et al. 1999, Lactin et al. 1995, Logan et al. 1976). The models were estimated by the LevenbergMarquardt method, using the minpack.lm package (Elzhov et al. 2016) of the R application version 3.4.0 (R Development Core Team 2017). The selection of the models was performed using a Chi-square $\left(\chi^{2}\right)$ test, the adjusted determination coefficient ( $R^{2}$ adj), residual square sum (RSS), Akaike information criterion (AIC) and maximum likelihood logarithm (LogLIK).

The number of monthly $D$. fovealis generations (NG) was calculated for the five main strawberryproducing municipalities of the State of Espírito Santo (Venda Nova do Imigrante, Domingos Martins, Vargem Alta, Santa Maria de Jetibá and Muniz Freire) utilizing the equation $N G=\{T$ $\left.\left(T_{\mathrm{m}}-T_{\mathrm{t}}\right) / K\right\}$, where $T$ is the number of days per month and $T_{\mathrm{m}}$ is the average temperature for the locality under study. To calculate the number of annual generations was used the cumulative 
TABLE I

Nonlinear models evaluated to describe the relationship between temperature and development rate $\left(r(T)\right.$, in days $\left.{ }^{-1}\right)$ for Duponchelia fovealis.

\begin{tabular}{cccc}
\hline Model & Parameters & Equation & Reference \\
\hline Briere-1 & 3 & $r(T)=a \cdot T \cdot\left(T-T_{0}\right) \cdot \sqrt{\left(T_{L}-T\right)}$ & Briere et al. (1999) \\
Logan-6 & 4 & $r(T)=\Psi \cdot\left[e^{\rho \cdot T}-e^{\left(\rho \cdot T_{L}-\frac{\left(T_{L}-T\right)}{\Delta}\right)}\right]$ & Logan et al. (1976) \\
Lactin-1 & 3 & $r(T)=e^{\rho \cdot T}-e^{\left(\rho \cdot T_{L}-\frac{\left(T_{L}-T\right)}{\Delta}\right)}$ & Lactin et al. (1995) \\
\hline
\end{tabular}

TABLE II

Development time (days) of different life stages of Duponchelia fovealis reared on artificial diet at five constant temperatures.

\begin{tabular}{cccccc}
\hline Temp. $\left({ }^{\circ} \mathrm{C}\right)$ & Egg $^{\mathrm{b}}$ & Larva $^{\mathrm{b}}$ & Pre-pupa $^{\mathrm{a}}$ & Pupa $^{\mathrm{b}}$ & Total $^{\mathrm{a}}$ \\
\hline 18 & $10.0 \pm 0.00 \mathrm{a}$ & $50.4 \pm 2.06 \mathrm{a}$ & $4.1 \pm 0.1 \mathrm{a}$ & $18.3 \pm 0.30 \mathrm{a}$ & $82.9 \pm 1.85 \mathrm{a}$ \\
21 & $7.0 \pm 0.00 \mathrm{ab}$ & $31.1 \pm 1.13 \mathrm{ab}$ & $2.6 \pm 0.03 \mathrm{~b}$ & $11.9 \pm 0.15 \mathrm{ab}$ & $52.6 \pm 1.23 \mathrm{~b}$ \\
24 & $5.0 \pm 0.00 \mathrm{bc}$ & $19.9 \pm 0.46 \mathrm{bc}$ & $1.9 \pm 0.02 \mathrm{c}$ & $8.5 \pm 0.07 \mathrm{bc}$ & $35.4 \pm 0.51 \mathrm{c}$ \\
27 & $4.0 \pm 0.00 \mathrm{c}$ & $17.9 \pm 0.49 \mathrm{c}$ & $1.3 \pm 0.04 \mathrm{~d}$ & $7.0 \pm 0.12 \mathrm{~cd}$ & $30.3 \pm 0.48 \mathrm{~d}$ \\
30 & $4.0 \pm 0.00 \mathrm{c}$ & $15.1 \pm 0.40 \mathrm{c}$ & $1.0 \pm 0.02 \mathrm{e}$ & $6.5 \pm 0.09 \mathrm{~d}$ & $26.6 \pm 0.41 \mathrm{~d}$ \\
\hline
\end{tabular}

Values are expressed as mean \pm SE, different letters indicate statistically significant differences according to $\left({ }^{\mathrm{a}}\right)$ Tukey’s test or $\left({ }^{\mathrm{b}}\right)$ Dunn's test at $5 \%$ probability.

number of monthly generations. The temperature data (monthly average between 2006 and 2015) of each municipality were provided by the Capixaba Institute for Research, Technical Assistance and Rural Extension (INCAPER).

\section{RESULTS}

The European pepper moth was observed to complete its development at all the temperatures studied. Temperature was found to vitally affect the egg to adult developmental cycle $\left(F_{4,45}=476.2\right.$; $P<0.001$ ), which was 26.6 and 82.9 days at 30 and $18{ }^{\circ} \mathrm{C}$, respectively (Table II). The incubation period lasted from four days at $30{ }^{\circ} \mathrm{C}$ to ten days at $18{ }^{\circ} \mathrm{C}\left(H_{4}=49.0 ; P<0.001\right)$ (Table II). Larval development extended to 15.1 and 50.4 days at 30 ${ }^{\circ} \mathrm{C}$ and $18{ }^{\circ} \mathrm{C}$, respectively $\left(H_{4}=45.1 ; P<0.001\right.$; Table II). The pre-pupal stage was observed for only a single day at $30{ }^{\circ} \mathrm{C}$ and 4.1 days at 18 ${ }^{\circ} \mathrm{C}$, with crucial differences noted among all the temperatures $\left(F_{4,45}=517.8 ; P<0.001\right.$; Table II $)$. The time of development of the pupal phase $\left(H_{4}=\right.$ $46.3 ; P<0.001)$ was inversely proportional to the rise in temperature (Table II).

The lower thermal thresholds $\left(T_{0}\right)$ and degreedays values $(K)$ were estimated by the common linear model over the linear response range (Table III). On extrapolating the linear regression lines of the developmental rate and temperature, the $T_{0}$ value for each developmental stage of $D$. fovealis was reported to be between 10.1 and $14.5^{\circ} \mathrm{C}$ (Table III). The $T_{0}$ for the egg, larval, pre-pupal and pupal phases were 10.1, 12.3, 14.5 and 11.1, respectively (Table III). The $K$ values were 73, 256, 16 and 116 degree-days, for the egg, larval, pre-pupal and pupal phases, respectively (Table III). The $T_{0}$ 
TABLE III

Estimates of linear regression parameters, min. temp. threshold $\left(T_{0}\right)$, and thermal constant $(K)$ for Duponchelia fovealis under laboratory conditions.

\begin{tabular}{ccccccc}
\hline Stage & $\chi^{2}$ & $p$-value & $R^{2}$ adj & RSS & AIC & LogLIK \\
\hline Egg & 0.0023 & 0.9999993 & 0.9216 & 0.001035714 & -22.2211 & 14.1106 \\
Larval & 0.0004 & 0.9999999 & 0.9643 & 0.00003729 & -38.8414 & 22.4207 \\
Pre-pupal & 0.0072 & 0.9999936 & 0.9769 & 0.006322168 & -13.1763 & 9.5881 \\
Pupal & 0.0008 & 0.9999999 & 0.9769 & 0.000180638 & -30.9529 & 18.4765 \\
Egg to adult & 0.0002 & 0.9999999 & 0.9740 & 0.00000840 & -46.2930 & 26.1465 \\
\hline Stage & $T_{0}\left({ }^{\circ} \mathrm{C}\right)$ & $K($ degree days $)$ & & Linear equation & $\mathrm{y}=-0.137143+0.013571 * \mathrm{~T}$ \\
Egg & 10.1 & 73.53 & & $\mathrm{y}=-0.0483159+0.0038826 * \mathrm{~T}$ \\
Larval & 12.3 & 256.41 & & $\mathrm{y}=-0.932636+0.063227 * \mathrm{~T}$ \\
Pre-pupal & 14.5 & 16.63 & & $\mathrm{y}=-0.0951752+0.0085742 * \mathrm{~T}$ \\
Pupal & 11.1 & 116.26 & & $\mathrm{y}=-0.0260595+0.0021685 * \mathrm{~T}$ \\
Egg to adult & 11.7 & 454.54 & &
\end{tabular}
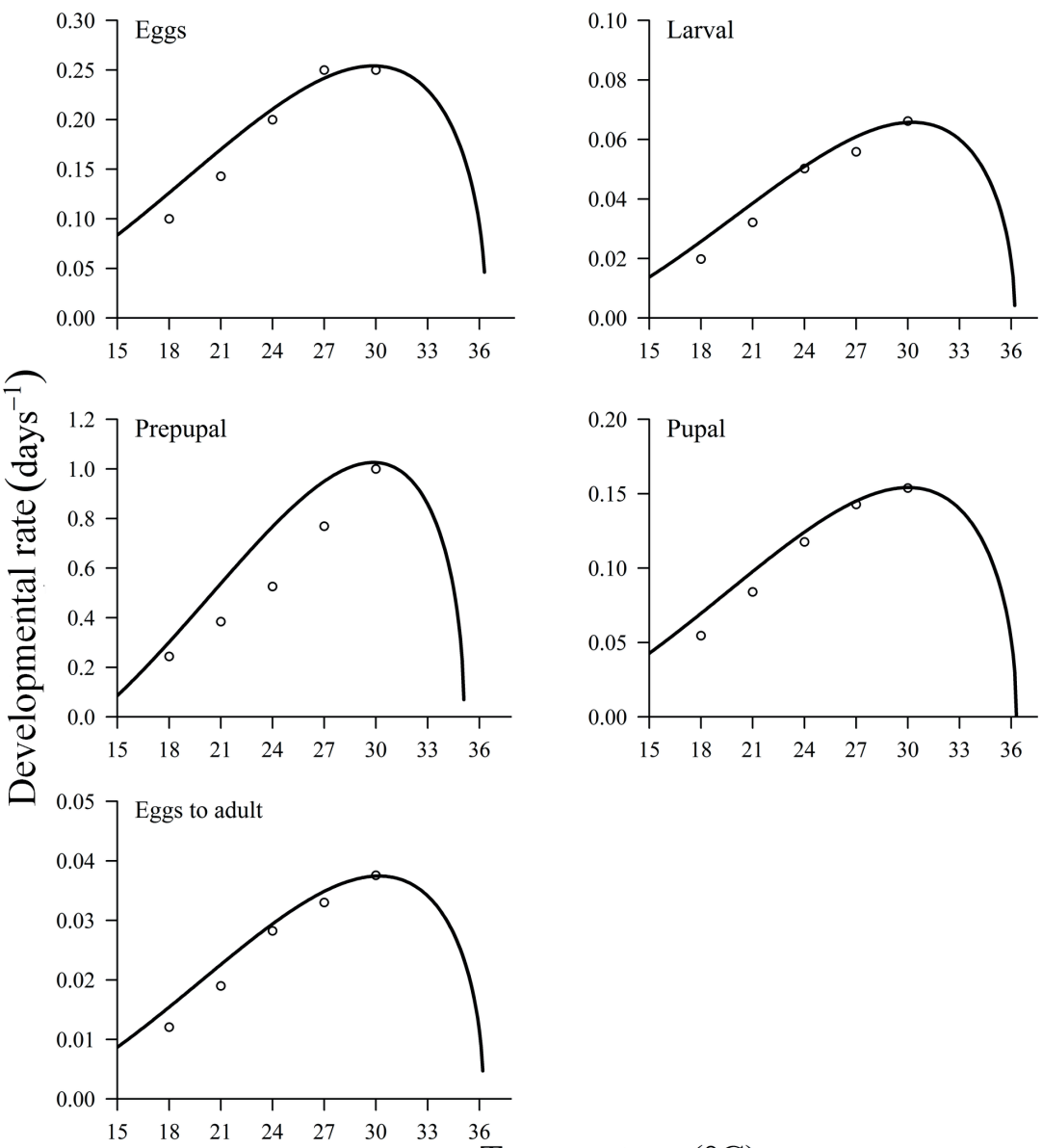

\section{Temperature $\left({ }^{\circ} \mathrm{C}\right)$}

Figure 1 - Temperature-dependent developmental rates (days $\left.{ }^{-1}\right)$ of egg, larval, pre-pupal, pupal stages and cycle of Duponchelia fovealis described by the Briere-1 model. Circles indicate observed values, while curves represent the model. 
TABLE IV

Estimated coefficients, thermal constants, and goodness of fit for nonlinear models for Duponchelia fovealis, under laboratory conditions.

\begin{tabular}{|c|c|c|c|c|c|c|}
\hline \multirow{2}{*}{ Model } & \multirow{2}{*}{ Parameter } & \multicolumn{5}{|c|}{ Stage } \\
\hline & & Egg & Larval & Pre-pupal & Pupal & Egg to adult \\
\hline \multirow[t]{10}{*}{ Briere-1 } & $\mathrm{a}$ & 0.000143 & 0.000045 & 0.000955 & 0.000095 & 0.000025 \\
\hline & $T_{0}\left({ }^{\circ} \mathrm{C}\right)$ & 6.57 & 10.61 & 13.11 & 8.52 & 9.95 \\
\hline & $T_{\mathrm{L}}\left({ }^{\circ} \mathrm{C}\right)$ & 36.39 & 36.21 & 36.11 & 36.30 & 36.24 \\
\hline & $T_{\text {opt }}\left({ }^{\circ} \mathrm{C}\right)$ & 29.61 & 29.97 & 30.56 & 29.77 & 29.91 \\
\hline & $\chi^{2}$ & 0.0488 & 0.0226 & 0.9464 & 0.0364 & 0.0114 \\
\hline & $p$-value & 0.99999 & 0.99999 & 0.9999896 & 0.99999 & 0.99999 \\
\hline & $R^{2}$ adj & 0.9683 & 0.9808 & 0.9426 & 0.9426 & 0.9907 \\
\hline & RSS & 0.000809 & 0.000045 & 0.055553601 & 0.000132106 & 0.0000067 \\
\hline & AIC & -42.8872 & -65.9201 & -9.0558 & -57.3878 & -81.2698 \\
\hline & LogLIK & 25.4436 & 36.9600 & 8.5279 & 32.6939 & 44.6349 \\
\hline \multirow[t]{11}{*}{ Lactin-1 } & $\rho$ & 0.134909 & 0.15381 & 0.192566 & 0.143151 & 0.150141 \\
\hline & $\Delta$ & 7.375064 & 6.496907 & 5.176557 & 6.969182 & 6.657375 \\
\hline & $T_{0}\left({ }^{\circ} \mathrm{C}\right)$ & - & - & - & - & - \\
\hline & $T_{\mathrm{L}}\left({ }^{\circ} \mathrm{C}\right)$ & 37.17 & 36.74 & 36.39 & 36.96 & 36.81 \\
\hline & $T_{\text {opt }}\left({ }^{\circ} \mathrm{C}\right)$ & 29.78 & 30.24 & 31.21 & 29.98 & 30.15 \\
\hline & $\chi^{2}$ & 0.0441 & 0.0198 & 0.8487 & 0.0323 & 0.0100 \\
\hline & $p$-value & 0.99999 & 0.99999 & 0.999994 & 0.999998 & 0.999998 \\
\hline & $R^{2}$ adj & 0.9364 & 0.9598 & 0.9964 & 0.9964 & 0.9723 \\
\hline & RSS & 0.0015168 & 0.0000886 & 0.003225093 & 0.000356301 & 0.000018 \\
\hline & AIC & -37.8618 & -60.5810 & -31.8269 & -49.4504 & -73.1178 \\
\hline & LogLIK & 22.9309 & 34.2905 & 19.9134 & 28.7252 & 40.5589 \\
\hline \multirow[t]{12}{*}{ Logan-6 } & $\Psi$ & 0.07309 & 0.008523 & 0.029945 & 0.03398 & 0.007272 \\
\hline & $\rho$ & 0.12973 & 0.145407 & 0.146595 & 0.1373 & 0.144502 \\
\hline & $\Delta$ & 7.08855 & 6.136941 & 3.837922 & 6.68123 & 6.404738 \\
\hline & $T_{0}\left({ }^{\circ} \mathrm{C}\right)$ & - & - & - & - & - \\
\hline & $T_{\mathrm{L}}\left({ }^{\circ} \mathrm{C}\right)$ & 37.17 & 36.74 & 36.37 & 36.96 & 36.81 \\
\hline & $T_{\mathrm{opt}}\left({ }^{\circ} \mathrm{C}\right)$ & 30.08 & 30.60 & 32.53 & 30.28 & 30.40 \\
\hline & $\chi^{2}$ & 0.0441 & 0.0198 & 0.8234 & 0.0323 & 0.0100 \\
\hline & $p$-value & 0.99999 & 0.99999 & 0.9999952 & 0.99999 & 0.999998 \\
\hline & $R^{2} \mathrm{adj}$ & 0.9204 & 0.9497 & 0.9962 & 0.9962 & 0.9653 \\
\hline & RSS & 0.00151776 & 0.00008865 & 0.00266812 & 0.000356519 & 0.000019 \\
\hline & AIC & -35.8567 & -58.5792 & -31.3436 & -47.4455 & -71.1122 \\
\hline & LogLIK & 22.9283 & 34.2896 & 20.6718 & 28.7228 & 40.5561 \\
\hline
\end{tabular}


and $K$ values for the complete development (from egg to adult) were $11.7^{\circ} \mathrm{C}$ and 454 degree-days, respectively (Table III).

The non-linear models evaluated were adjusted by the Chi-square test and high values of $R^{2}$ adj in the distinct stages of development of $D$. fovealis (Table IV). However, the careful analysis of AIC and LogLIK revealed that the Briere-1 model showed a better fit for all stages of development (Table IV, Figure 1). Based on the Briere-1 model, were estimated the upper thresholds $\left(T_{\mathrm{L}}\right)$ and the optimum temperature $\left(T_{\text {opt }}\right)$. The $T_{\mathrm{L}}$ values were close to $36^{\circ} \mathrm{C}$, while $T_{\text {opt }}$ values were between 29.61 and $30.56{ }^{\circ} \mathrm{C}$ at distinct stages of development of D. fovealis (Table IV). The predicted value of the developmental rate as a function of temperature is presented (Figure 1).

Temperature was seen to greatly influence the shape of the survival curves $(\operatorname{LogRank}$ Test $=$ 357.86; $P<0.001$ ), showing that the life-time of the insect was inversely proportional to the temperature (Figure 2).

For the $D$. fovealis adults, the average longevity was found to be inversely proportional

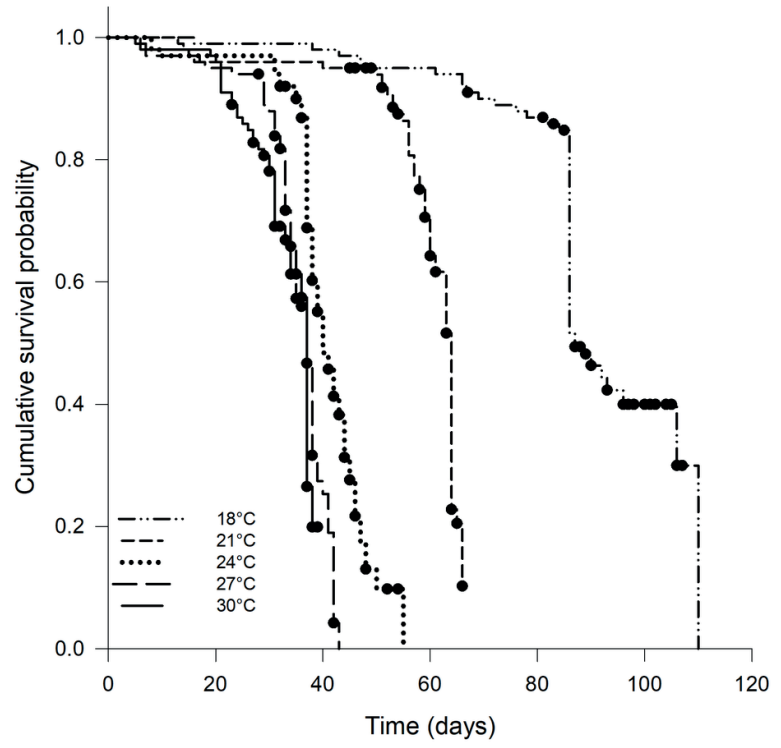

Figure 2 - Survival curves of Duponchelia fovealis at five constant temperatures.

to temperature and varied significantly among the treatments for males $\left(F_{4,105}=28.11 ; P<0.001\right)$ and females $\left(F_{4,83}=29.41 ; P<0.001\right.$; Table V).

The annual $D$. fovealis generations was determined to be $6.1,5.7,5.2,5.5$ and 4.8 for the Muniz Freire, Domingos Martins, Santa Maria de

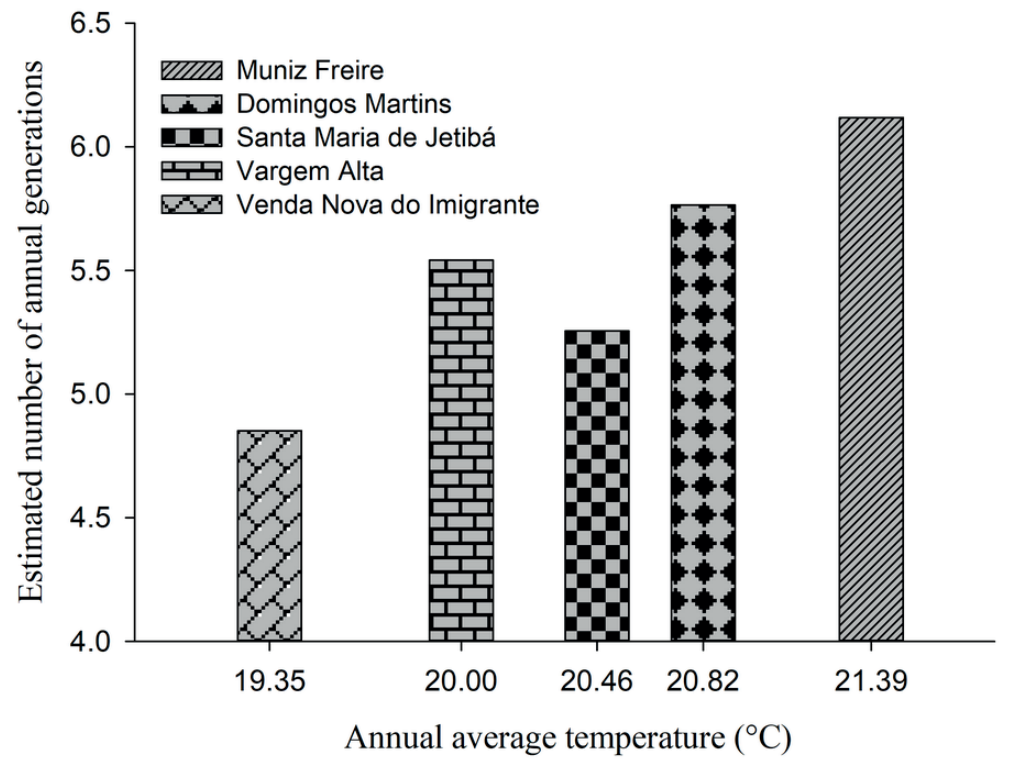

Figure 3 - Estimated number of annual Duponchelia fovealis generations in the five main strawberry producing municipalities of Espírito Santo State. 


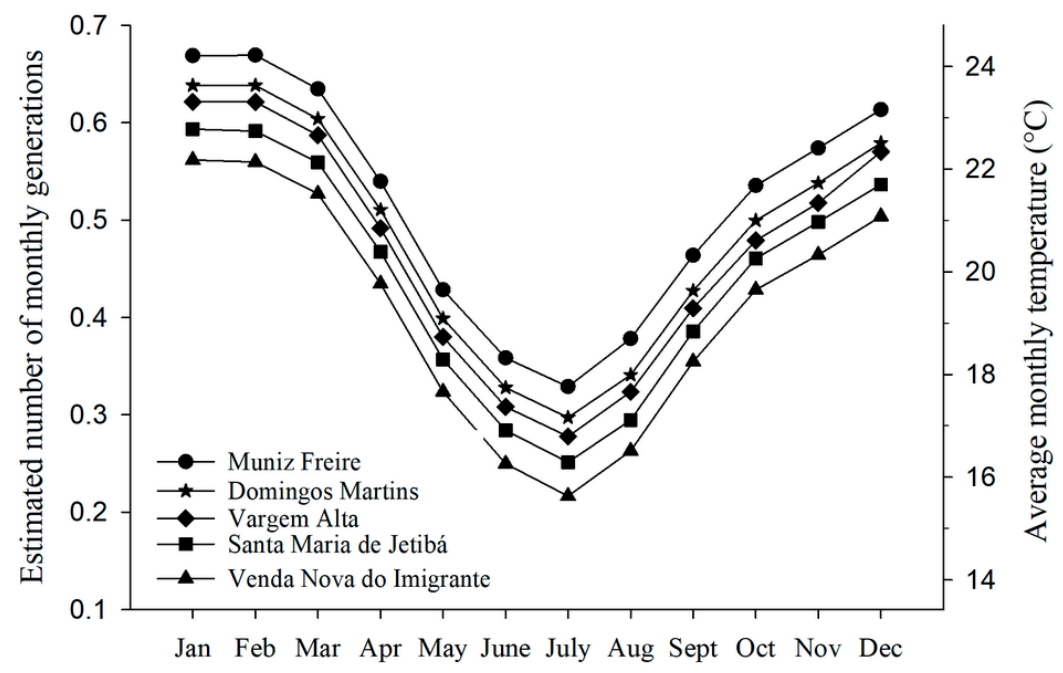

Figure 4 - Estimated number of monthly Duponchelia fovealis generations in the five main strawberry producing municipalities of Espírito Santo State.

TABLE V

Longevity (days) of males and females adults of Duponchelia fovealis at five constant temperatures.

\begin{tabular}{ccc}
\hline Temperature $\left({ }^{\circ} \mathrm{C}\right)$ & Male & Female \\
\hline 18 & $16.8 \pm 1.13 \mathrm{a}$ & $14.7 \pm 1.20 \mathrm{a}$ \\
21 & $10.9 \pm 0.92 \mathrm{bc}$ & $13.2 \pm 0.92 \mathrm{a}$ \\
24 & $9.2 \pm 1.12 \mathrm{c}$ & $9.8 \pm 1.07 \mathrm{~b}$ \\
27 & $6.6 \pm 0.61 \mathrm{~cd}$ & $6.8 \pm 0.77 \mathrm{c}$ \\
30 & $5.1 \pm 0.49 \mathrm{~d}$ & $5.0 \pm 0.65 \mathrm{c}$ \\
\hline
\end{tabular}

Values are expressed as mean $\pm \mathrm{SE}$, different letters in column indicate statistically significant differences (Tukey's test, $P<0.05$ ).

Jetibá, Vargem Alta and Venda Nova do Imigrante municipalities, respectively (Figure 3). When the monthly variations in the number of $D$. fovealis generations were analyzed, a large drop (0.21 to 0.38 generations per month) was noted between June and August, when the temperatures dipped below $18{ }^{\circ} \mathrm{C}$; but between December and February, an increase in the number of generations was seen ( 0.5 to 0.67 ) with temperatures ranging from 21 to $24.2{ }^{\circ} \mathrm{C}$ (Figure 4).

\section{DISCUSSION}

The current study was the first to analyze the influence of temperature on $D$. fovealis development. The results clearly verified that temperature influenced all the developmental stages of life of the European pepper moth, in which the development time increased at lower temperatures, when there was a drop from 30 to $18{ }^{\circ} \mathrm{C}$. Such an influence of temperature on insect development can be attributed to the behavioral plasticity of the ectotherms (Sunday et al. 2014), which require an appropriate temperature to optimize the working of their physiological processes (Krechemer and Foerster 2015). The metabolic processes of insects increase at high temperatures, and consequently their developmental time is reduced (Akbar et al. 2016, Martins et al. 2016). However, the lower temperatures decrease the metabolic rate and lengthen the time of insect development (Marchioro and Foerster 2011); under conditions of extreme cold, ionic imbalance is induced, causing impairment of neuromuscular function, resulting in chill-coma (MacMillan and Sinclair 2011).

The development rate for $D$. fovealis estimated in the current study was adjusted to the linear model for all the developmental phases. Normally, the relationship between the developmental rate and temperature is curvilinear near the extreme temperatures, and roughly linear at moderate ones (Liu et al. 1995, Liu et al. 2015). Nonlinear 
mathematical models have been applied to arrive at a more accurate estimate at longer thermal intervals (Orang et al. 2014, Sandhu et al. 2010). However, in this study only a small thermal range (18 to $30{ }^{\circ} \mathrm{C}$ ) was evaluated, although it was sufficient to estimate, with good significance, the thermal constants and lower temperature thresholds. These can prove very useful for predictions in many studies (Malaquias et al. 2014, Moraes and Foerster 2015). Therefore, in this study the linear model presented better adjustment for $K$ and $T_{0}$, while the nonlinear models estimated $T_{\text {opt }}$ and $T_{\mathrm{L}}$. Linear models complement information from nonlinear models and vice versa, since linear models rarely estimate $T_{\text {opt }}$ and $T_{\mathrm{L}}$, whereas nonlinear models do not always accurately estimate $K$ e $T_{0}$ (Koda and Nakamura 2012, Roltsch et al. 1990, Tofangsazi et al. 2012).

The base temperature or lower thermal threshold required for $D$. fovealis to develop its egg to adult cycle was estimated at $11.7{ }^{\circ} \mathrm{C}$. The development of insects can be influenced by latitude, with the lower thermal threshold decreasing with increasing latitude. Populations of insects living in temperate regions have a lower base temperature $\left(7.9^{\circ} \mathrm{C}\right)$ than those living in subtropical $(10.5$ ${ }^{\circ} \mathrm{C}$ ) or tropical $\left(13.7{ }^{\circ} \mathrm{C}\right)$ regions (Honek 1996). Therefore, the base temperature estimated in this study indicates that the $D$. fovealis populations of the Espírito Santo State are adapted to the regions that are between subtropical and tropical climate. Among species of the Crambidae family there seems to be no climate-related preference pattern. For example, Palpita nigropunctalis (Bremer) showed a base temperature of $6.8^{\circ} \mathrm{C}$ (Gotoh et al. 2011), Neoleucinodes elegantalis (Guenée) $8.8^{\circ} \mathrm{C}$ (Moraes and Foerster 2015) and Herpetogramma phaeopteralis (Guenée) $13.1{ }^{\circ} \mathrm{C}$ (Tofangsazi et al. 2012), indicating that Crambidae family is widely distributed among different latitudes.

In $D$. fovealis, adult longevity and survival from egg to adult were negatively influenced by the rise in temperature. A similar pattern was noted in Tuta absoluta (Lep.: Gelechiidae) (Krechemer and Foerster 2015) and N. elegantalis (Moraes and Foerster 2015), in which increased survival was seen in response to a temperature drop, implying a linear relationship. However, studies on Plutella xylostella (L.) (Lep.: Yponomeutidae) (Marchioro and Foerster 2011) and Helicoverpa armigera (Lep.: Noctuidae) (Mironidis and SavopoulouSoultani 2008) revealed a nonlinear survival pattern, with the use of more extreme temperatures, below 18 and above $30{ }^{\circ} \mathrm{C}$. Insects subjected to such temperature conditions normally revealed a U-curved pattern, with greater mortality at the extreme temperatures and lower mortality within the curve, between 15 and $25^{\circ} \mathrm{C}$ (Liu et al. 1995).

The annual generations of the European pepper moth ranged in number from 4.8 to 6.1 generations in the five strawberry-producing municipalities of Espírito Santo State. The small degree of variation resulted from the marginal difference in the average annual temperatures among the municipalities, which hovered in the range of 19.3 to $21.3{ }^{\circ} \mathrm{C}$. A larger variation would be observed if the localities were located at distant latitudes. For $N$. elengatalis, 10.9 annual generations were reported at latitude $00^{\circ} 02^{\prime} 19^{\prime \prime} \mathrm{N}$ and 5.8 generations at $25^{\circ} 25^{\prime} 47^{\prime \prime} \mathrm{S}$, a difference of roughly $25^{\circ}$ distance (Moraes and Foerster 2015). However, the most geographically distant municipalities considered in this study are only 38 minutes away, such as Santa Maria de Jetibá $\left(20^{\circ} 02 ' 26^{\prime}\right.$ 'S) and Vargem Alta (2040'17'S). Estimating the number of generations can facilitate the management of $D$. fovealis because it helps to predict the number of generations that can arise in a year, and more accurately within a given month. For instance, the largest number of generations was recorded between December and February, regardless of the municipality, indicating that even in these places identical population dynamics can be expected. However, there are other variables that have not been analyzed in the current study, 
like diet (Tofangsazi et al. 2012), host plant (Jing et al. 2016), and estimation technique (Liu et al. 2015, Orang et al. 2014) may influence the development and number of generations and must be taken into account in the European pepper moth management programs.

Temperature changes directly affect insects and although this study was conducted using constant temperatures, the results obtained can be practically applied because $D$. fovealis is usually reported as a greenhouse pest, where controlled temperatures are the norm. The accurate assessments of the thermal requirements of $D$. fovealis can enable the prediction of population growth, revealing the best times for sampling the insects for monitoring, and whether such checks must be initiated or intensified. This will facilitate planning the phytosanitary pest management programs.

\section{ACKNOWLEDGMENTS}

The authors would like to thank the Fundação de Amparo à Pesquisa e Inovação do Espírito Santo (FAPES), the Conselho Nacional de Desenvolvimento Científico e Tecnológico (CNPq) and the Financiadora de Estudos e Projetos (FINEP) for financial support; and the Instituto Capixaba de Pesquisa, Assistência Técnica e Extensão Rural (INCAPER) for the supply of climate data.

\section{REFERENCES}

AHERN R. 2010. Amended New Pest Advisory Group Report. Duponchelia fovealis Zeller: Lepidoptera/ Pyralidae. UF/ IFAS Pest Alert: 7. Available at: http://entomology.ifas. ufl.edu/pestalert/Duponchelia_fovealis_NPAG_ET_ Report_20100917.pdf [Accessed October 3, 2016]. AKBAR SM, PAVANI T, NAGARAJA T AND SHARMA HC. 2016. Influence of $\mathrm{CO} 2$ and Temperature on Metabolism and Development of Helicoverpa armigera (Noctuidae: Lepidoptera). Environ Entomol 45: 229-236.

BAVARESCO A, GARCIA MS, GRÜTZMACHER AD, FORESTI J AND RINGENBERG R. 2002. Biologia e exigências térmicas de Spodoptera cosmioides (Walk.) (Lepidoptera: Noctuidae). Neotrop Entomol 31: 49-54.
BETHKE JA AND BATES LM. 2014. European pepper moth. Cent Invasive Species Res. Available at: http://cisr.ucr.edu/ european_pepper_moth.html [Accessed October 3, 2016].

BONSIGNORE CP AND VACANTE V. 2010. Duponchelia fovealis (Zeller). Une nuova emergenza per la fragola? Prot delle Colt 3: 40-43.

BRAMBILA J AND STOCKS I. 2010. The European pepper moth, Duponchelia fovealis Zeller (Lepidoptera: Crambidae), a Mediterranean pest moth discovered in central Florida. Pest Alert DACS-P-01752, Florida Dept Agric Consum Serv Div Plant Ind, p. 1-4.

BRIERE J-F, PRACROS P, LE ROUX A-Y AND PIERRE JS. 1999. A Novel Rate Model of Temperature-Dependent Development for Arthropods. Environ Entomol 28: 22-29.

CAMPBELLA, FRAZER BD, GILBERT N, GUTIERREZ AP AND MACKAUER M. 1974. Temperature Requirements of Some Aphids and Their Parasites. J Appl Ecol 11: 431438.

ELZHOV TV, MULLEN KM, SPIESS AN AND BOLKER B. 2016. minpack.lm: R Interface to the Levenberg-Marquardt Nonlinear Least-Squares Algorithm Found in MINPACK, Plus Support for Bounds. R package version 1.2-1.

FORNAZIER MJ ET AL. Praga exótica no Estado do Espírito Santo: Duponchelia fovealis Zeller, 1847 (Lepidoptera: Crambidae). Incaper, Doc 198: 4.

GOTOH T, KOYAMA M, HAGINO Y AND DOKE K. 2011. Effect of leaf toughness and temperature on development in the lilac pyralid, Palpita nigropunctalis (Bremer) (Lepidoptera: Crambidae). J Asia Pac Entomol 14: 173178.

GREENE GL, LEPPLA NC AND DICKERSON WA. 1976. Velvetbean caterpillar: a rearing procedure and artificial medium. J Econ Entomol 69: 487-488.

HONEK A. 1996. Geographical variation in thermal requirements for insect development. Eur J Entomol 93 303-312.

JING J, XIA L AND LI K. 2016. Development of defoliating insects and their preferences for host plants under varying temperatures in a subtropical evergreen forest in eastern China. Front Earth Sci: 1-11.

KANG L, CHEN B, WEI J-N AND LIU T-X. 2009. Roles of Thermal Adaptation and Chemical Ecology in Liriomyza Distribution and Control. Annu Rev Entomol 54: 127-145.

KAPLAN ELAND MEIER P. 1958. Nonparametric Estimation from Incomplete Observations. J Am Stat Assoc 53: 457.

KODA K AND NAKAMURA H. 2012. Effects of temperature on the development and survival of an endangered butterfly, Lycaeides argyrognomon (Lepidoptera: Lycaenidae) with estimation of optimal and threshold temperatures using linear and nonlinear models. Entomol Sci 15: 162-170.

KRECHEMER FS AND FOERSTER LA. 2015. Tuta absoluta (Lepidoptera: Gelechiidae): Thermal requirements and effect of temperature on development, 
survival, reproduction and longevity. Eur J Entomol 112: 658-663.

LACTIN DJ, HOLLIDAY NJ, JOHNSON DLAND CRAIGEN R. 1995. Improved Rate Model of Temperature-Dependent Development by Arthropods. Environ Entomol 24: 68-75.

LIU J-F, YANG M-F, HU J-F AND HAN C. 2015. Effects of Temperature on Development and Survival of Orthopygia glaucinalis (Lepidoptera: Pyralidae) Reared on Platycarya strobilacea. J Econ Entomol 108: 504-514.

LIU S-S, ZHANG G-M AND ZHU J. 1995. Influence of Temperature Variations on Rate of Development in Insects: Analysis of Case Studies from Entomological Literature. Ann Entomol Soc Am 88: 107-119.

LOGAN JA, WOLLKIND DJ, HOYT SC AND TANIGOSHI LK. 1976. An Analytic Model for Description of Temperature Dependent Rate Phenomena in Arthropods 1. Environ Entomol 5: 1133-1140.

MACMILLAN HA AND SINCLAIR BJ. 2011. Mechanisms underlying insect chill-coma. J Insect Physiol 57: 12-20.

MALAQUIAS JB ET AL. 2014. The Biology and Thermal Requirements of the Fennel Aphid Hyadaphis foeniculi (Passerini) (Hemiptera: Aphididae). PLoS ONE 9: e100983.

MANFREDI-COIMBRA S, GARCIA MS AND BOTTON M. 2001. Exigências Térmicas e Estimativa do Número de Gerações de Argyrotaenia sphaleropa (Meyrick) (Lepidoptera: Tortricidae). Neotrop Entomol 30: 553-557.

MARCHIORO C AND FOERSTER L. 2011. Development and survival of the diamondback moth, Plutella xylostella (L.) (Lepidoptera: Yponomeutidae) as a function of temperature: effect on the number of generations in tropical and subtropical regions. Neotrop Entomol 40: 533-541.

MARTINS JC, PICANÇO MC, BACCI L, GUEDES RNC, SANTANA PA, FERREIRA DO AND CHEDIAK M. 2016. Life table determination of thermal requirements of the tomato borer Tuta absoluta. J Pest Sci (2004) 89: 897-908.

MIRONIDIS GK AND SAVOPOULOU-SOULTANI M. 2008. Development, Survivorship, and Reproduction of Helicoverpa armigera (Lepidoptera: Noctuidae) Under Constant and Alternating Temperatures. Environ Entomol 37: 16-28.

MORAES CP AND FOERSTER LA. 2015. Thermal Requirements, Fertility, and Number of Generations of Neoleucinodes elegantalis (Guenée) (Lepidoptera: Crambidae). Neotrop Entomol 44: 338-344.

ORANG FS, AGHDAM HR, ABBASIPOUR H AND ASKARIANZADEH A. 2014. Effect of Temperature on Developmental Rate of Sesamia cretica (Lepidoptera: Noctuidae) Immature Stages. J Insect Sci 14: 1-7.

ROLTSCH WJ, MAYSE MA AND CLAUSEN K. 1990. Temperature-Dependent Development Under Constant and Fluctuating Temperatures: Comparison of Linear Versus Nonlinear Methods for Modeling Development of Western Grapeleaf Skeletonizer (Lepidoptera: Zygaenidae). Environ Entomol 19: 1689-1697.

SANDHU HS, NUESSLY GS, WEBB SE, CHERRY RH AND GILBERT RA. 2010. Temperature-Dependent Development of Elasmopalpus lignosellus (Lepidoptera: Pyralidae) on Sugarcane Under Laboratory Conditions. Environ Entomol 39: 1012-1020.

SOUZA JC, SILVA RA, SILVEIRA EC, ABREU FA AND TOLEDO MA. 2013. Ocorrência de nova praga nas lavouras de morango no Sul de Minas. EPAMIG, Circ Técnica (180): 1-5.

STOCKS SD AND HODGES A. 2013. European Pepper Moth or Southern European Marsh Pyralid Duponchelia fovealis (Zeller). Dep Entomol Nematol UF/IFAS Extension, Gainesville, FL 32611 Doc EENY-508: 10. Available at: http://entnemdept.ufl.edu/creatures/veg/leps/european pepper_moth.htm.

SUNDAY JM, BATES AE, KEARNEY MR, COLWELL RK, DULVY NK, LONGINO JT AND HUEY RB. 2014. Thermal-safety margins and the necessity of thermoregulatory behavior across latitude and elevation. Proc Natl Acad Sci USA 111: 5610-5615.

TOFANGSAZI N, BUSS EA, MEAGHER R, MASCARIN GM AND ARTHURS SP. 2012. Thermal Requirements and Development of Herpetogramma phaeopteralis (Lepidoptera: Crambidae: Spilomelinae). J Econ Entomol 105: 1573-1580.

ZAWADNEAK MAC, GONÇALVES RB, PIMENTEL IC, SCHUBER JM, SANTOS B, POLTRONIERI AS AND SOLIS MA. 2016. First record of Duponchelia fovealis (Lepidoptera: Crambidae) in South America. Idesia (Arica) 34: 91-95. 